\title{
CHEMICAL BONDING SUCCESSFUL LEARNING USING THE “CHEBO COLLECT GAME": A CASE STUDY
}

\author{
Achmad Lutfi (iD, Rusly Hidayah (D), Sukarmin Sukarmin (D), Kusumawati Dwiningsih (D) \\ Chemistry Education, Mathematics and Natural Sciences Faculty, \\ Universitas Negeri Surabaya, Surabaya (Indonesia) \\ achmadlutfi@unesa.ac.id,ruslybidayah@unesa.ac.id,sukarmin@unesa.ac.id,kusumawatidwiningsib@unesa.ac.id
}

Received March 2021

Accepted May 2021

\section{Abstract}

The use of games in the chemistry learning process has a positive effect on students' behaviour, understanding, and interest in the discussed topics. A Chebo Collect (chemical bonding collects) game, which has met validity, practicality, and effectiveness criteria, was used as a medium to learn chemical bonds. This study aimed to assess the use of computerized games as learning media on chemistry subjects based on the learning activities, students' responses, and the impact of learning objectives achievement. This study was conducted in high schools in East Java, Indonesia with 32 students as the subject for a game teaching method and 30 students as control using a traditional method. The students' activities were observed during the learning process and the tests were done by using a questionnaire. The results revealed that the learning activities were more student-centered methods and the learning outcomes reached classical completeness with the significant differences between the initial and final test scores. Students also gave positive responses to the use of Chebo collect game as a medium to learn chemical bonds. The Chebo Collect game has succeeded in helping students to learn chemical bonds. This method has created student-centered learning and it could improve students' learning outcomes.

Keywords - Game, Chebo collect, Bonding chemistry, Gamification success.

\section{To cite this article:}

Lutfi, A., Hidayah, R., Sukarmin, S., \& Dwiningsih, K. (2021). Chemical bonding successful learning using the "Chebo Collect game": A case study. Journal of Technology and Science Education, 11(2), 474-485. https://doi.org/10.3926/jotse.1265

\section{Introduction}

Chemistry learning activities have a variety of sources, references, and kinds of literature that can provide convenience to teachers and students. Aside from books as the primary learning source, the use of electronic media can also be beneficial as they help deliver teachers' messages, information, and knowledge to students. The use of electronic media not only helps the teacher in the learning process but also provides an added value to the learning activities (Nordby, Øygardslia, Sverdrup \& Sverdrup, 2016). Concerning chemistry, there are times when the information from the teacher is interpreted differently by the students. The more teachers verbally interpret the learning material, the harder it is for students to understand (Smaldino, Lowther \& Clif, 2019). Therefore, we need a medium that can elucidate the teacher's interpretation and make it less verbal. This way, the students will have a better understanding of 
the learning material. The use of appropriate learning media will enable the students to learn quickly and actively participate in the learning process (Indriana, 2011). However, the media options to learn chemistry according to the latest material's characteristics are still low (Gilbert, 2005).

One way to facilitate students in learning abstract materials is by using computers (Osman \& Bakar, 2014), e.g., computer-assisted games. Game is an exciting way to help students learn both science and related vocabularies. The implementation of educational games in the classroom is considered more motivating than conventional learning because games are widely enjoyed by the public today. According to Virvou, Katsionis and Manos (2005), game technology can motivate students to learn and actively involve the students, thus leading to more fun and effective learning process. Cheng, She and Annetta (2015) also stated that fun and excitement from the game could motivate the players and provide great potential for use in learning. Other study results revealed that a learning process with an integrated medium is effective to increase the students' understanding and interest in the discussed topics. The use of games in the chemistry learning process has a positive effect on students' behavior and the students do not necessarily be in class in the process (Cahyana, Paristiowati, Savitri \& Hasyrin, 2017).

Chemistry has a lot of topics but the key concept to learn chemistry is the Chemical Bonding topic. Since it is a fundamental topic, the students should understand this first before continuing to the next advanced topic. However, many researchers found that the students met difficulties while studying this topic (Nahum, Mamlok-Naaman, Hofstein \& Taber, 2010; Komisia \& Leba, 2018; Dawati, Yamtinah, Rahardjo, Ashadi \& Indriyanti, 2019). Chemical Bonding is an abstract topic, and it will be bored to study just by using a handbook. The students' understanding is also influenced by the presentation of the handbook and the style that the author used (Bergqvist, 2017). Therefore, there should be an innovation in the learning media for the chemical bond topic with technological developments, such as Computer Assisted Instruction or games since computer and games are globally liked by kids or students. Well-designed games that are applied in the education context are effective to motivate students as the students will feel playing when they are learning. The use of games as media can motivate students to achieve specific goals; in this case, the planned learning goal is called "gamification". During the game, students are engaged in high-level cognitive activities to encourage retention, activity, and trial and error. Games can be associated with learning experiences through appropriate designs. An educational game has relevant and challenging problem-solving scenarios, to allow the students to build, try, and assimilate new knowledge (Nordby et al., 2016). The Chebo Collect Game is one solution for the application of gamification in the learning process.

Currently, Chebo Collect (chemical bonding collect) game has met the validity, practicality, and effectiveness criteria as a medium to learn chemical bonds (Hilmiyah \& Lutfi, 2017). The game is an offline 2D adventure investigation game about chemical bonding, designed for high school students, and played on a computer or laptop. The game is designed as a learning medium for chemical bonds and is expected to help students to achieve learning goals by playing simple investigations. The game has 3 levels with increasing difficulty in each level. The theme of level 1 is garden; level 2 is forest, and level 3 is a mini labyrinth. Students will be challenged to accomplish missions at each level by answering questions about chemical bonds. If they cannot answer, the Help menu can be used. Furthermore, lives are reduced when the students are unable to fight the monsters in the game (Hilmiyah \& Lutfi, 2017). This way, the student's boredom can be expected to reduce during chemistry bond learning. This game promotes the pedagogic aspects as a learning media, maintained politeness, and the appearance of violence or hatred, e.g., killing and hurting others, is avoided in this game (Lutfi, 2017).

The purpose of this study is to observe the effect of computer games as a learning medium on achieving successful learning in chemical bonds topics based on the students' activities, learning outcomes, and student responses to the game. Besides, this study was expected to provide new and more effective media to learn relevant subjects. A new method for learning activity is required for a better quality of learning and educational outcomes. 


\section{Literature Review}

The technological advancement diversifies the media in the teaching and learning process so it could be tailored based on the student's condition, time, financial, and teaching material. Teaching media has the contribution to increase the quality of the teaching and learning process as well as aiding the teacher in the process (Carrillo, Carcia, Laguna, Magan, Alberto \& Morena, 2019). One of the principles in the teaching-learning process using technological information is to increase its efficiency and effectiveness. The technology could increase student motivation and make the student more active in the process so it could shift the focus to the students, not the teachers (Sánchez-Mena \& Martí-Parreño, 2017). However, the real application is not without challenges. Teachers found it difficult to use the media for several reasons, such as learning difficulties, students do not like it, and unsuitable for the learning goals.

An unattractive learning atmosphere could be alleviated using innovative learning media. One of those learning media is a game, which makes the students more active by playing the game so it could give a diverse learning process experience (Smaldino et al., 2019). The game has several advantages, such as it could be tailored to be challenging, fun, and close to the students (Kuo \& Chuang, 2016). The game could train the students skills in problem-solving and help them master the knowledge and skills in its wake as a teaching-learning media (Indriana, 2011). A game also has the potential to be applied in the education system as it could bring happiness during the learning by making it more recreative (Cheng et al., 2015; Kuo \& Chuang, 2016). Several studies stated that the computer-based games could increase the student's motivation based on the individual's learning perspective (Aldrich, 2005), enabling the students to be involved in an interactive learning environment (Kiili \& Lainema, 2006), and increasing the student's information retention and problem-solving skill (Gros, 2007).

Chemistry learning game is hoped to increase the student's motivation in learning chemistry, information speed processing, and social sensitivity. The media could give numerous learning experience that effectively gains the student's attention to learn a particular topic or skill (Smaldino et al., 2019). A well-designed game will give more benefits to the teaching-learning process than a lecture-based process (Cheng et al., 2015).

However, the educational learning goals could be lost due to the bigger desire to win than the desire to learn. This desire could happen if the game is heavy on the playing part than in the learning part or if the game is designed without considering the specific goal targets. Thus, the eligibility needs to be assessed before the game is used in the teaching-learning process. Most of the games accentuate the violence, without concrete goals, and give more rewards to the winner than focus on the pedagogical process. Even though the game is designed for education, it will not be useful if the pedagogical process is incorrect (Kiili \& Lainema, 2006). Similar to other media, games could make the wrong concept impression, so they should be designed with the pedagogical as the primary concern (Lutfi, 2017).

\section{Method}

\subsection{Study Context}

This study used a one-group pretest-posttest design to evaluate the effect of independent and dependent variables measured in two time periods (Knapp, 2016).

The game, titled Chebo Collect game, is a $2 \mathrm{D}$ adventure investigation game about chemical bonding. In this game, the students were challenged by using several questions. The game has 3 levels with a different theme at each level. The game also has information about the learning competency (core competencies, basic competencies, learning goals, and assessment indicator). The first level is the garden, the second one is the forest, and the last is the labyrinth. The higher the level, the harder the difficulty will be. Each level has challenges (regular and bonus challenges) corresponding to the material. The player should solve at least 8 out of 10 challenges correctly in the allocated time to proceed to the next level, and each correct answer will net in the score in form of a coin. If the player cannot solve the challenge, then 3 coins will be deducted from the player. The player has a life or opportunity to answer, in form of the flower, that could be added by each correct answer. The "lihat materi" (look at material) menu has the material corresponding 
to the challenge in the form of texts, figures, and videos. After completing the challenge, the player's score will be displayed. The teaching materials in the game are covalent bonds, Lewis' Theory, coordination covalent bonds, and polar and non-polar substances (Figure 1).
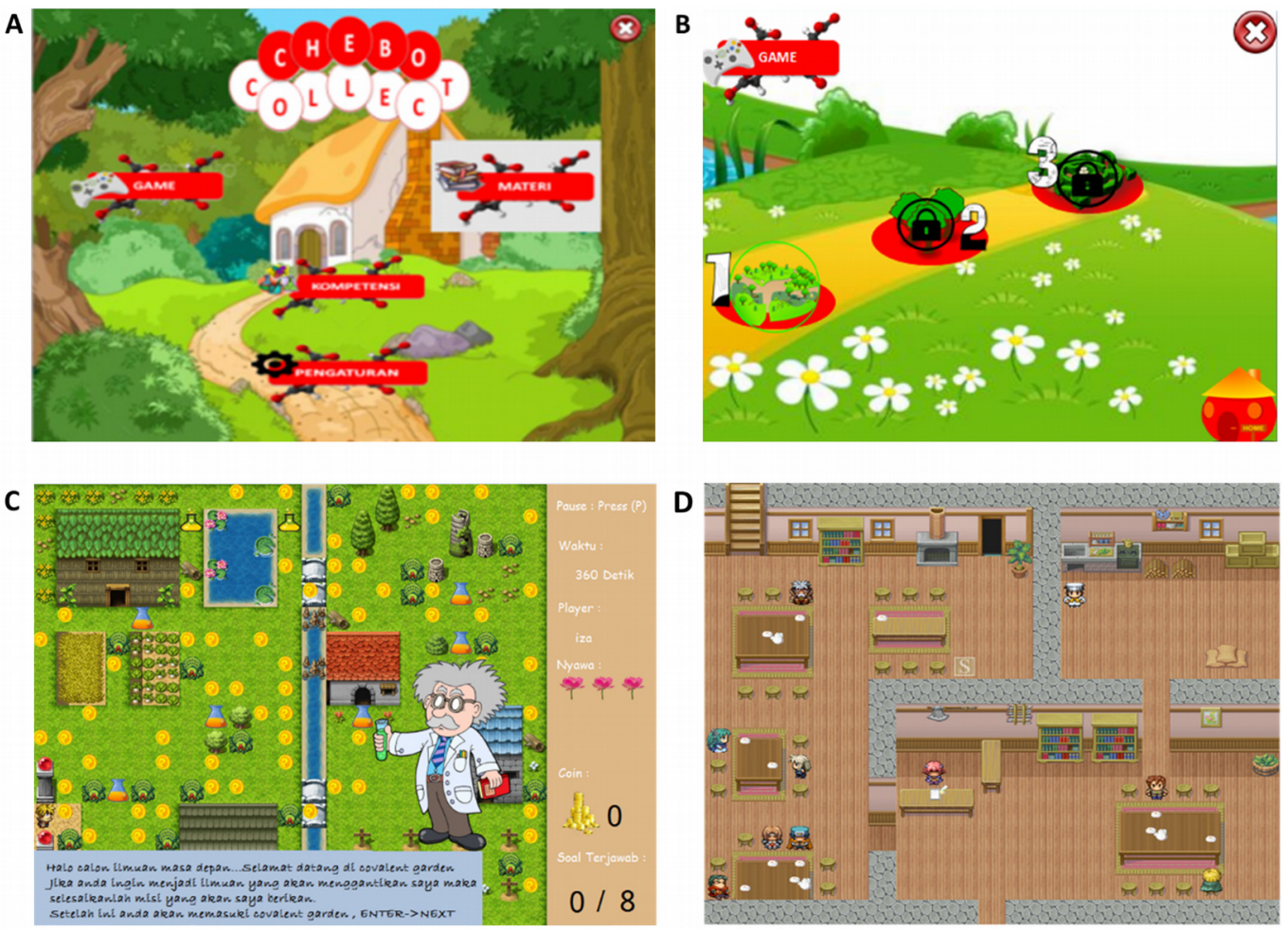

Figure 1. The Chebo collect game design. A. Main menu. B. Level select. C. Level 1, the gardens. D. The player looking for literature in the game

\subsection{Previous Study}

The preliminary study revealed that from 125 students who studied chemical bonds, $90.63 \%$ stated that learning about chemical bonds was difficult. This was followed by the under-performed learning outcome scores of $52 \%$, below the standard of $80 \%$. The previous study has found that the use of games in learning can solve student's misconceptions. The results of the preliminary study conducted on the frequency of students playing at the school in which the initial study of 128 grade $\mathrm{X}$ students is presented in Figure 2.

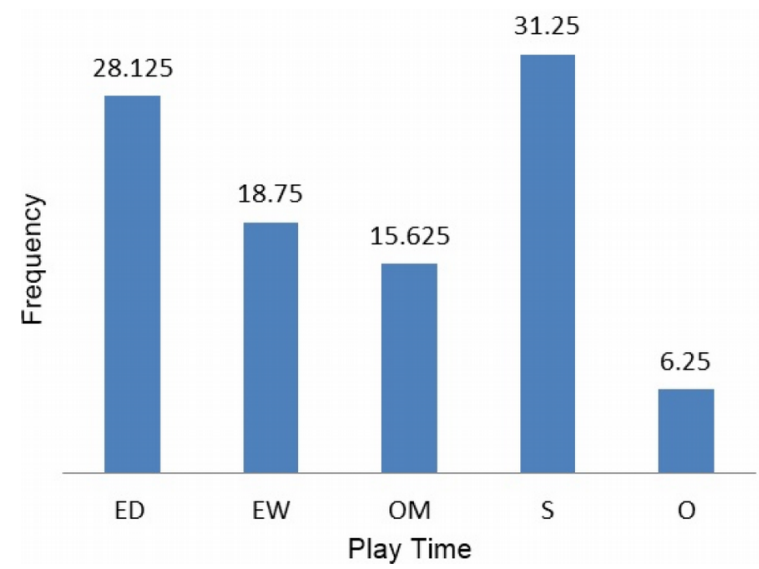

Figure 2. The frequency of students playing the Chebo Collect game. ED: Every day;

EW: Every week; OM: Every month; S: Sporadically; O:

Others 
Figure 2 shows that all students involved in playing, with $\mathrm{S}$ having the most significant frequency $(31.25 \%)$, followed by ED (28.13\%); the results of the previous research revealed that $75 \%$ of the students liked playing games and $93.75 \%$ agreed to use games as learning media in chemistry learning. The obtained data indicate that high school students often visit the play center after school time or during vacation.

\subsection{Participants}

This study included schools that have been accredited and had computer facilities in Gresik, East Java, Indonesia. The schools were randomly selected to be a control school and an experimental school. From those schools, the control class (from the control school) and experimental class (from the experimental class) were also randomly selected. It involved class X with 32 students. The students were $46.8 \%$ male and $53.2 \%$ female and 16-17 years old. The participants should have the competency to learn chemical bonds topics such as familiar with electron configuration, electron valence, atoms, molecules, and compounds. The familiarity was based on the test result on those mentioned topics in the school, which should exceed 75. For control, there were randomly selected 30 class X students. The control group was given the conventional teaching and learning method using the conventional classroom setting instead of the game setting. The inclusion criteria are the same as the participant group.

\subsection{Instrumentation}

The instrument to collect the data was the student's activity observation sheet, questionnaire for students, and pretest with a posttest to assess the learning process. The instruments were validated by three experts of Chemical Education from Malang University and the State University of Surabaya using a Likert scale on these aspects: (1) instrument suitability with goal indicator; (2) concept and content; (3) language; and (4) instrument's difficulty level. The validation score was $78 \%, 85 \%$, and $91 \%$, which is considered to be high-very high (Arifin, 2011). Kuder-Richardson 20 (KR-20) was used to check the instruments' reliability and the reliability score for each instrumentation was $0.83,0.88$, and 0.9 , which is considered valid (Sudijono, 2011).

\subsection{Data Collection Procedures}

The Chebo Collect game was played for $2 \times 45$ min. The students' activities were observed during the learning process and the tests were done twice, before and after the learning process. Tests were conducted to determine students' abilities. The questionnaires were distributed to students for them to answer to obtain their responses and the learning outcomes of the game. The control group was only given the pretest and posttest.

\subsection{Data Analysis}

The student activity data on each observation aspect was analyzed based on the frequency of the grading scale and the assessment results were categorized as very often, often, rather often, rarely, and never. Meanwhile, the learning achievement test was analyzed by calculating each individual's completeness scores and classical completeness. Individual completeness had a minimum score of $75 \%$, and classical completeness should reach a minimum of $80 \%$. A paired t-test was also conducted to determine the significant differences between the initial and the final test score. The normality test and the paired t-test were conducted using the SPSS software (IBM, USA). Student responses to positive and negative statements were scored and are presented in Table 1.

\begin{tabular}{|c|r|r|}
\hline Statement & \multicolumn{1}{|c|}{ Answer Score “yes” } & Answer Score “no" \\
\hline Positive & 1 & 0 \\
\hline Negative & 0 & 1 \\
\hline
\end{tabular}

Table 1. Student questionnaire scoring

The percentage was calculated using the following formula: 


$$
\mathrm{P}=(\mathrm{M} / \mathrm{T}) \times 100 \%
$$

Notes:

P: Presentation of student choice score for each statement

M: Student choice score

T: Total number of students who filled out the questionnaire.

The student responses were considered as positive or successful if the student choice score was greater than $75 \%$ on each statement.

\section{Results}

\subsection{Student's Activity}

The student's activities were observed to obtain the extent of the Chebo Collect game as a learning medium to induce student-centered learning. The results of the observations of student activities from the experiment group are presented in Table 2.

The student activities observation score during learning reached 2.64 in the frequent category, which means that students are actively involved during the learning process and the game makes the process student-centered. This result is following Park's results (Park, 2012), which stated that games could create highly active student activities during learning.

\begin{tabular}{|l|r|r|}
\hline \multicolumn{1}{|c|}{ Observed Aspects } & Observation Results \\
\cline { 2 - 3 } & P 1 & P 2 \\
\hline AQ - Asking a question & 4 & 4 \\
\hline PP - Provide input on the problem being presented & 3 & 3 \\
\hline FN - Find something new (different) & 3 & 2 \\
\hline TCT - Try challenging tasks & 3 & 3 \\
\hline DA - Describes answers found in other friends & 2 \\
\hline WC - Willingness to come to the front of the class & 2 \\
\hline $\begin{array}{l}\text { QR - Questioning the results of the teacher or student's work and comparing them with } \\
\text { their answers }\end{array}$ & 2 \\
\hline Total & 2 \\
\hline Average & 19 \\
\hline
\end{tabular}

Information: P1 - observer 1; P2 - observer 2

Table 2. The observation results of student activity

\subsection{Learning Outcomes}

The learning outcomes tests are conducted before and after learning to obtain information about students' abilities before and after learning, so it can see the impact of the Chebo Collect game as a chemical bond learning media. The student's learning outcomes from both experiment and control groups are presented in Table 3.

The results above indicate that the initial test scores did not reach students' completeness, while the final test scores obtained classical completeness of $93.7 \%$ and had reached the specified criteria for the experiment group. The normality test results show that the significant values were 0.123 and 0.088 for the experiment and control (greater than 0.050), which means that both groups are normally distributed. The value of $\mathrm{t}$ arithmetic was -49.70 , with a degree of freedom of 31 and a t-table value of 2.04 showed that the $t$ arithmetic was in the Ho rejection area, meaning that there is a significant difference between the average of the initial and the final score. Meanwhile, the control group did similarly with the control at the initial test, but the post-test showed only $20 \%$ of the students had reached the $80 \%$ classical completeness even though there was a significant difference between pretest and posttest in the control group 
statistically. These results indicate that learning chemical bonds using the Chebo Collect game can lead to successful learning outcomes.

Table 3 shows the success of using the Chebo Collect game as a medium for learning chemical bonds in students' learning outcomes when compared to conventional classroom teaching. Another study conducted on three high school grades X and XI in East Java, Indonesia, the use of games as learning media was shown to increase learning outcomes in learning some chemistry topics, such as acid bases, chemical elements, and hydrocarbons (Lutfi, Suyono, Erman \& Hidayah, 2019). This statement is possible because games make the learning process more interesting and exciting (Freitas, 2010).

On the other hand, teachers believe that "gamification" can increase the attention and motivation of students. This condition seems to have particular relevance to the teaching of the younger generation who are no longer interested in traditional pedagogical approaches (Sánchez-Mena \& Martí-Parreño, 2017). Another advantage is that students who learn by playing exhibit better visual, psychomotor, and affective abilities (Aguilera \& Mendiz, 2003).

\begin{tabular}{|c|c|c|c|c|c|c|c|}
\hline \multirow[b]{2}{*}{ Score } & \multirow{2}{*}{$\begin{array}{c}\text { Number of } \\
\text { students }\end{array}$} & \multirow[b]{2}{*}{ Complete } & \multicolumn{2}{|c|}{ Score $(\max 100)$} & \multirow[b]{2}{*}{ sig } & \multirow[b]{2}{*}{ df } & \multirow[b]{2}{*}{$t$ count } \\
\hline & & & Lower & Highest & & & \\
\hline \multicolumn{8}{|l|}{ Control } \\
\hline Pretest & 30 & $1(3.33 \%)$ & 3.33 & 80 & .250 & \multirow{2}{*}{29} & \multirow{2}{*}{-12.65} \\
\hline Posttest & 30 & $6(20.0 \%)$ & 56.67 & 90 & .108 & & \\
\hline \multicolumn{8}{|l|}{ Experiment } \\
\hline Pretest & 32 & $0(0.0 \%)$ & 5 & 40 & .123 & \multirow{2}{*}{31} & \multirow{2}{*}{-49.70} \\
\hline Posttest & 32 & $30(93.7 \%)$ & 65 & 90 & .088 & & \\
\hline
\end{tabular}

Table 3. Students' learning outcomes

\subsection{Student Feedback Questionnaire}

The students' responses to the learning of the chemical bond using games are presented in Table 4 . The data was only obtained from the experiment group.

\begin{tabular}{|c|c|c|c|c|}
\hline \multirow[b]{2}{*}{ No } & \multirow[b]{2}{*}{ Types of Statement } & \multicolumn{2}{|c|}{ Answer } & \multirow{2}{*}{$\begin{array}{c}\text { Preferred Score } \\
\%\end{array}$} \\
\hline & & “yes" & “no" & \\
\hline \multirow{5}{*}{1} & a) I feel learning chemistry by playing is easier. & 31 & 1 & 96.8 \\
\hline & $\begin{array}{l}\text { b) After learning chemistry using the game, I became happier in } \\
\text { studying chemistry. }\end{array}$ & 30 & 2 & 93.7 \\
\hline & c) I want to study chemistry again using games. & 31 & 1 & 96.8 \\
\hline & d) If possible, I want to take the game home to study at home. & 30 & 2 & 93.7 \\
\hline & e) I want to tell friends or parents about learning chemistry & 29 & 3 & 90.6 \\
\hline \multirow{3}{*}{$2^{*}$} & a) I feel that learning chemistry was too long & 0 & 32 & 100 \\
\hline & b) I feel learning chemistry using this game is boring & 1 & 31 & 96.8 \\
\hline & c) I want to study chemistry without using the game & 1 & 31 & 96.8 \\
\hline
\end{tabular}

* Negative statements

Table 4. Student questionnaire result

The students' responses toward positive statements are explained below. The lowest percentage of "yes" answers to the positive statements was $90.6 \%$, and the lowest percentage of "no" answers to negative statements was $96.8 \%$. These results meet the specified criteria, where at least $75 \%$ of students gave positive responses. The results show that students gave a positive response or agree on using a game as a learning medium. This result is consistent with Hilmiyah and Lutfi's result (2017), which stated that high 
school students favor computer games as a learning media for the chemical bond topic. Students' interest in the Chebo Collect game is also high, which makes it a good capital for learning chemistry.

On the statement of "I feel learning chemistry by playing is easier", the presentation score was $96.8 \%$ and only $3.2 \%$ of students who said "no", due to the said student is regarded as smart in chemistry and can learn in any way possible. On the statement of "After used the chemistry learning game, I became happier in studying chemistry", there were two students who answered "no", which means that they did not enjoy learning chemistry even after used the game. Those students stated that they enjoy learning chemistry through a book and using a game as a learning media is quite different.

There was a student who answered "no" on the "I want to study chemistry again using the games", statement. After a thorough search, it was found that the student thought it was impossible to play again because he did not own the game. On the "If possible, I want to take the game home to study at home" statement, there were two students who answered "no", which means that they do not want to bring home the game program. The students clarified that they did not have a laptop or a computer at home. On the "I want to tell friends or parents about learning chemistry" statement, there were only 3 students who answered "no", while the rest answered "yes", which means that almost all students wanted to tell their friends or parents about the experience in learning chemistry using games. Those who stated "no" said to be concerned that their parents will think they are playing at the game center or have no one to talk to due to living alone, or due to their reserved habits.

Students' responses toward negative statements are explained below. On the statement of "I feel that learning chemistry was too long", almost all students answered "no", which means that learning by playing with computer games was entertaining for them; thus, they did not feel that learning was too long. On the statements of "I feel learning chemistry using this game is boring" and "I want to study chemistry without using the game", only one student stated "yes" from each statement that came from the same student, meaning that only one person declared the game as boring and wanted to learn without using the game. Learning using the game will prolong his time in school.

The results of the students' responses above indicate that the game facilitated their learning. It encourages them to have enjoyable learning, to continue learning, and to complete the stages of the game.

The reasons for the students' negative responses, such as not agreeing with the use of the game as a medium for learning chemistry, are personal conditions or the uniqueness and characters of the students themselves, such as the limited time in school, the availability of laptops, and students' habit in their homes. Some of the students were asked why they did not like using the games as learning media. The answer was that they preferred non-digital games in which they can move their body when playing instead of just sitting and operating a laptop/computer. Also, when another student was asked why he did not like to study earlier, he answered that he did not have a laptop but had a mobile phone. These findings indicate that there should be another form of the game besides the computer or laptop game. Moreover, it is recommended that learning should not rely on one media; there should be other media as alternatives.

\section{Discussion}

The students gave good responses to the use of games as a medium for learning chemistry based on the comparison with conventional teaching (Table 3). The questionnaire results showed that the game can improve their motivation and interest in learning chemical bonds. Students also stated that the game was fun and made them excited to learn chemistry. These were observed during the process; the students looked happy when learning and playing. Some students asked to bring the game home. These results indicated that the game has succeeded as a good learning medium and the game has made it easier for students to learn.

Table 2 and 4 shows that learning chemistry with games increase students' excitement and make a conducive learning atmosphere. This result is in accord with the opinion stated by Meier (2000) about games as a learning media. The excitement means that the student's involvement is increased, which also increases the creation of meaning, understanding, and enjoyment in learning for students. It is because the 
game has the components of competition, challenges, cooperation, rewards, and taking the advantage of opportunities.

These results are consistent with previous studies, which stated that the game in the classroom can make students feel enthusiastic (Rastegarpour \& Marashi, 2012) and motivate them to learn (Pivec \& Kearnet, 2007). Games can significantly increase students' enthusiasm for learning (Cordova \& Lepper, 1996). Games can also attract and entertain players at the same time (Kiili \& Lainema, 2006). When students are familiar with the games, the students are eager to complete the games. (Agarwal \& Saha, 2011).

The use of computer-assisted learning media can help students to overcome the difficulties in learning chemical bonds at the submicroscopic level. This result of the development of a submicroscopic level is represented through visual media (Farida, 2012). These results are consistent with those of Agarwal and Saha's (2011) study on learning chemistry using computerized games; the game enabled the students to get an average score of 4.1 or $82 \%$, which is considered as a good result. Other researchers also stated that the game could significantly improve learning outcomes (Cordova \& Lepper, 1996); has a positive effect on problem-solving and learning achievement (Kiili \& Lainema, 2006); and can be useful tools in learning chemical concepts when used appropriately (Bolinggi, 2009). Activities in the game provide more intelligence training through sound, images, linguistics, kinesthetic, and interpersonal and intrapersonal intelligence. Likewise, the results of Rastegarpour and Marashi's (2012) study indicated that there were significant differences in the learning outcomes between the experimental group and the control group and can make students involved in the learning process, yet its success also depends on how the game is used optimally as a learning media.

The above results indicated that the game has succeeded in creating active students and encouraging students to continue learning. Learning using computerized games allows the students to build knowledge from ambiguity by repeatedly attempting the game to acquire new knowledge. This is consistent with Piaget's fundamental insight that individuals construct their understanding and learning as a constructive process. Vygotsky, the founder of constructivism, believes that cultural tools, including computers, play a significant role in cognitive development. Constructivism argues that students can construct or build their knowledge with active processes, diverse learning resources, and provide opportunities for students to collaborate. All these activities are in a computerized game (Woolfolk, 2009).

Learning using games as a media can provide a rich learning environment, helping students build knowledge at a higher level and skills through ambiguous, challenging, and opportunities (Van, 2007). During the play, the students are engaged in a high-level cognitive activity that encourages their attention, activity, and retention by trial and error in the game. With this being said, the usage of games to do the teaching and learning process is feasible to do. However, due to the limitation of the study, in which the experiment was done in one school and limited to one topic only, we could argue that the gamification of the teaching and learning process could be applicable for other topics as well. The trend of mobile app development could increase the mobility and the convenience of the game as the current version of the Chebo Collect game is only available on a PC or laptop.

\section{Conclusion}

The Chemo Collect Game has been developed to help the students to learn The Chemical Bonding topic. The assessment was conducted by directly implemented in the class. The results showed that the Chebo Collect Game could help the students to learn chemical bonds. It increased the student's active participation, created the learning student-centered, improved the students' learning outcomes so the outcome target could be achieved. The students were supported to learn chemical bonds by using computer games.

In the future, gamification can be used as an option in education, especially as a learning medium. The game should be assisted by a computer and tested for validity, practicality, and effectiveness to assess whether it can be used as a medium for learning chemistry and as an alternative teaching medium for teachers. 


\section{Declaration of Conflicting Interests}

The authors declared no potential conflicts of interest with respect to the research, authorship, and/or publication of this article.

\section{Funding}

The authors received no financial support for the research, authorship, and/or publication of this article.

\section{References}

Agarwal, M., \& Saha, S. (2011). Learning chemistry through the puzzle-based game: atoms to a molecule. Paper presented at 9th IEEE International Conference on Emerging eLearning Tecbnologies and applications. Slovakia. https://doi.org/10.1109/ICETA.2011.6112613

Aguilera, M.D., \& Mendiz, A. (2003). Video games and education: Education in the face of a "parallel school". Computers in Entertainment, 1, 10. https://doi.org/10.1145/950566.950583

Aldrich, C. (2005). Learning by doing. New York: Wiley.

Arifin, Z. (2011). Evaluasi pembelajaran [Learning evaluation]. Malang: PT Remaja Rosdakarya.

Bergqvist, A. (2017). Teaching and learning of chemical bonding models. Doctoral Thesis. Karlstad University Studies.

Bolinggi, I. (2009). Educational computer games as effective learning tool. Available at: http://www.articlesbase.com

Cahyana, C., Paristiowati, M., Savitri, A., \& Hasyrin, S.N. (2017). Developing and application of mobile game based learning (M-GBL) for high school students' performance in chemistry. Journal of Mathematics, Science and Technology Education, 13(10), 7037-7047. https://doi.org/10.12973/ejmste/78728

Carrillo, D.L., Carcia, A.C., Laguna, T.R., Magan, G.R., Alberto, J., \& Morena, L. (2019). Using gamification in a teaching innovation project at the University of Alcalá: A new approach to experimental science practices. The Electronic Journal of e-Learning, 17(2), 93-106.

https://doi.org/10.34190/JEL.17.2.03

Cheng, M.T., She, H.C., \& Annetta, L.A. (2015). Game immersion experience: its hierarchical structure and impact on game-based science learning. Journal of Computer Assisted Learning, 31(3), 232-253. https://doi.org/10.1111/jcal.12066

Cordova, D.I., \& Lepper, M.R. (1996). Intrinsic motivation and the process of learning: Beneficial effects of contextualization, personalization, and choice. Journal of Educational Psychology, 88(34), 715-730. https://doi.org/10.1037/0022-0663.88.4.715

Dawati, F.M., Yamtinah, S., Rahardjo, S.B., Ashadi, A., \& Indriyanti, N.Y. (2019). Analysis of students' difficulties in chemical bonding based on computerized two-tier multiple-choice (CTTMC) test. International Conference on Mathematics and Science Education (ICMScE 2018). Journal of Physics: Conference Series, 1157. https://doi.org/10.1088/1742-6596/1157/4/042017

Farida, I. (2012). Interkoneksi multipel level representasi mahasiswa calon guru pada kesetimbangan dalam larutan melalui pembelajaran berbasis WEB [Multiple level interconnection of student teacher representation in equilibrium in solution through WEB-based learning]. Doctoral dissertation. Universitas Pendidikan Indonesia. Bandung, Indonesia.

Freitas, D. (2010). A game-based learning framework: linking game design and learning outcomes. Available at: http://sgi.cueltd.net/publications/papers/Chapter_Staalduinen_Freitas__Final.pdf

Gilbert, J.K. (2005). Visualization: A metacognitive skill in science education. In Gilbert, J.K. (Ed.), Visualization in science education (9-27). Berlin: Springer. https://doi.org/10.1007/1-4020-3613-2_2

Gros, B. (2007). Digital games in education: The design of games-based learning. Environments Journal of Research on Technology in Education, 40(1), 23-38. https://doi.org/10.1080/15391523.2007.10782494 
Hilmiyah, N.F., \& Lutfi, A. (2017). Pengembangan permainan chebo collect sebagai media pembelajaran pada materi pokok ikatan kimia untuk kelas X SMA [Development of the Chebo collect game as a learning medium on the subject matter of chemical bonding for class X SMA]. UNESA Journal of Chemical Education, 6(2), 219-228.

Indriana, D. (2011). Ragam alat bantu media pengajaran mengenal, merancang, dan mempraktikkannya [Various teaching media aids identify, design, and practice them]. Surabaya: DIVA Press.

Kiili, K., \& Lainema, T. (2006). Evaluations of an experiential gaming model: The real game case. In Pearson, E., \& Bohman, P. (Eds.), Proceedings of ED-MEDIA 2006--World Conference on Educational Multimedia, Hypermedia \& Telecommunications (2343-2350). Association for the Advancement of Computing in Education (AACE). Orlando, Florida, USA.

Knapp, T.R. (2016). Why is the one-group pretest-postest design still used? Clinical Nursing Research, 25(5), 467-472. https://doi.org/10.1177/1054773816666280

Komisia, F., \& Leba, M.A.U. (2018). The Effect of Problem Based Learning Model by Animation Media on Student Learning Outcomes in Senior High School on Chemical Bonding Topic. Proceedings of the Seminar Nasional Kimia - National Seminar on Chemistry (SNK 2018). Advances in Engineering Research, 171. https://doi.org/10.2991/snk-18.2018.34

Kuo, M.S., \& Chuang, T.Y. (2016). How gamification motivates visits and engagement for online academic dissemination - An empirical study. Computers in Human Behavior, 55, 16-27. https://doi.org/10.1016/j.chb.2015.08.025

Lutfi, A. (2017). Quality documents for the development of computerized games as learning media for Natural Sciences. Doctoral dissertation. Surabaya State University, Surabaya, Indonesia.

Lutfi, A., Suyono, S., Erman, E., \& Hidayah, R. (2019). Edutainment with as a chemistry learing media. Jurnal Penelitian Pendidikan Sains (JPPS), 8(2), 1784-1689. https://doi.org/10.26740/jpps.v8n2

Meier, D. (2000). The accelerated learning handbook. New York: McGraw-Hill.

Nahum, T.L., Mamlok-Naaman, R., Hostein, A., \& Taber, K. (2010). Teaching and Learning the Concept of chemical bonding. Studies in Science Education, 46(2):179-207.

https://doi.org/10.1080/03057267.2010.504548

Nordby, A., Øygardslia, K., Sverdrup, U., \& Sverdrup, H. (2016). The art of gamification; teaching sustainability and system thinking by pervasive game development. The Electronic Journal of e-Learning, 14(3), 152-168.

Osman, K., \& Bakar, N.A. (2014). Implementation of educational computer games in Malaysian chemistry classroom: challenges for game designers. Asian Social Science, 8(11), 156-162.

https://doi.org/10.5539/ass.v8n11p75

Park, H. (2012). Relationship between motivation and student's activity on the educational game. International Journal of Grid and Distributed Computing, 5(1), 101-114.

Pivec, M., \& Kearnet, P. (2007). Games for learning and learning from games. Organizacija, 31(6), 419-423.

Rastegarpour, H., \& Marashi, P. (2012). The effect of card games and computer games on learning chemistry concepts. Procedia - Social and Behavioral Sciences, 31, 597-601.

https://doi.org/10.1016/j.sbspro.2011.12.111

Sánchez-Mena, A., \& Martí-Parreño, J. (2017). Drivers and barriers to adopting gamification: teachers' perspectives. The Electronic Journal of e-Learning, 15(5), 434-443.

Smaldino, S.E., Lowther, D.L., \& Clif, M. (2019). Instructional technology and media for learning. London: Pearson Education.

Sudijono, A. (2011). Pengantar evaluasi pendidikan [Introduction to educational evaluation]. Depok: Rajawali Pers. 
Van, R.E. (2007). Six ideas in search of a discipline. In Shelton, B.E. \& Wiley, D.A. (Eds.), The design and use of simulation computer games in education (31-60). USA: Sense Publishers.

https://doi.org/10.1163/9789087903121_005

Virvou, M., Katsionis, G., \& Manos, K. (2005). Combining software games with education: evaluation of its educational effectiveness. Educational Technology \& Society, 8(2), 54-65.

Woolfolk, A. (2009). Educational psychology active learning. Yogyakarta: Pustaka Pelajar.

Published by OmniaScience (www.omniascience.com)

Journal of Technology and Science Education, 2021 (www.jotse.org)

\section{(c) (1) (3)}

Article's contents are provided on an Attribution-Non Commercial 4.0 Creative commons International License. Readers are allowed to copy, distribute and communicate article's contents, provided the author's and JOTSE journal's names are included. It must not be used for commercial purposes. To see the complete licence contents, please visit https://creativecommons.org/licenses/by-nc/4.0/. 